\title{
Protection of Stakeholders' Interests and Sustainable Development: A Critical Analysis of the Role of Government in the Mining Sector in South Africa
}

\author{
Linda Muswaka
}

Lecturer, Faculty of Law, North West University, South Africa

E-mail: leemuswaka@gmail.com

Doi:10.5901/mjss.2014.v5n2p395

\section{Abstract}

\begin{abstract}
Mining has been the main driving force behind the history and development of South Africa's economy. Mining continues to support and stimulate growth and development in the country. However, while mining has been the mainstay of the economy and has contributed significantly to the industrial development of the country, its impact on stakeholders such as the mine workers and the communities in which mining activities takes place has not been that significant. In this light, a matter of concern that arises is whether or not the interests of these stakeholders are protected. This article seeks to explore this issue. More importantly, the article examines the role of government in the mining sector. It will be argued that government has an important role to play in the mining sector in ensuring the protection of stakeholders' interests and promoting sustainable development and growth and recommendations will be made in this regard.
\end{abstract}

Keywords: Mining sector, Shareholders, Stakeholders, Government, Corporate Social Responsibility

\section{Introduction}

South Africa holds a major economic and physical presence on the African continent and the world at large regarding mining. About a quarter of South Africa's exports come from mining. South Africa ranks number five in the world in gold production ${ }^{1}$ and it is one of the largest producers of platinum in the world. ${ }^{2}$ Mining has been the mainstay of the economy and has contributed significantly to the industrial development of the country. However, its impact on stakeholders such as the mine workers and the communities in which mining activities takes place has not been that significant. In this light, a matter of concern that arises is whether or not the interests of these stakeholders are protected. This article seeks to explore this issue. More importantly, the article examines the role of government in the mining sector. It will be argued that government has an important role to play in the mining sector in ensuring the protection of stakeholders' interests and promoting sustainable development and growth and recommendations will be made in this regard.

\section{The Mining Industry and Economic Growth}

Mining has been the main driving force behind the history and development of South Africa's economy. Mining continues to support and stimulate growth and development in the country. The table below shows mineral sales in million rand from January 2006- November 2012.

\begin{tabular}{|c|c|c|c|c|c|c|c|}
\hline Month & $\mathbf{2 0 0 6}$ & $\mathbf{2 0 0 7}$ & $\mathbf{2 0 0 8}$ & $\mathbf{2 0 0 9}$ & $\mathbf{2 0 1 0}$ & $\mathbf{2 0 1 1} \mathbf{1 /}$ & $\mathbf{2 0 1 2} \mathbf{1 /}$ \\
\hline Jan & 11755,1 & 15692,9 & 17442,2 & 17263,9 & 19185,1 & 25367,7 & 28825,3 \\
\hline Feb & 12680,8 & 17928,6 & 21737,4 & 19906,3 & 20408,4 & 27544,0 & 30010,7 \\
\hline Mar & 14179,9 & 18555,2 & 25894,1 & 22093,9 & 23860,1 & 31486,9 & 31785,6 \\
\hline Apr & 13042,6 & 17447,8 & 25520,6 & 20733,6 & 23551,4 & 27388,9 & 27405,5 \\
\hline May & 14046,8 & 19841,6 & 26737,6 & 18463,5 & 25535,2 & 27851,9 & 32283,4 \\
\hline Jun & 17809,8 & 19033,2 & 29881,0 & 20337,3 & 25882,9 & 33949,7 & 34876,8 \\
\hline
\end{tabular}

\footnotetext{
1 See, "China, Ghana gold production spike, others fall" available at http://www.mining.com/world-gold-production-2012-preliminaryresults-71758/, accessed on 16 February 2013. South Africa was the world's largest gold producer until 2007 when China became the largest producer of gold. China continued to increase gold production (extraction) and remained the leading gold-producing nation in 2009, followed by Australia.

2 See Platinum Today, available at http://www.platinum.matthey.com/about-pgm/production, accessed on 12 March 2013.
} 


\begin{tabular}{|c|c|c|c|c|c|c|c|}
\hline Jul & 17614,8 & 17449,4 & 27164,7 & 20019,7 & 25588,6 & 27910,5 & 31688,0 \\
\hline Aug & 17339,2 & 17890,4 & 27064,3 & 20144,0 & 25897,8 & 30304,5 & 32042,0 \\
\hline Sep & 20586,6 & 19619,7 & 27830,7 & 20737,7 & 27994,7 & 35735,9 & 31123,6 \\
\hline Oct & 18031,0 & 18713,7 & 27191,4 & 19909,8 & 27535,5 & 33429,6 & 28860,9 \\
\hline Nov & 18918,2 & 20674,4 & 23991,0 & 20128,7 & 27114,9 & 35304,5 & 29811,1 \\
\hline Dec & 17584,7 & 21590,8 & 20259,5 & 21626,2 & 27737,9 & 34557,3 & \\
\hline Total & $193 \mathbf{5 8 9 , 5}$ & $\mathbf{2 2 4} \mathbf{4 3 7 , 7}$ & $\mathbf{3 0 0 7 1 4 , 5}$ & $\mathbf{2 4 1 3 6 4 , 6}$ & $\mathbf{3 0 0 2 9 2 , 5}$ & $\mathbf{3 7 0} \mathbf{8 3 1 , 4}$ & \\
\hline
\end{tabular}

1/ Preliminary.

\section{Source: Statistics South Africa ${ }^{3}$}

Mining companies contribute extensively to South Africa's tax base. For instance, in 2009 mining created roughly R10.5 billion in corporate tax receipts ${ }^{4}$ and contributed $8.8 \%$ directly and $10 \%$ indirectly to the country's gross domestic product (GDP). ${ }^{5}$ It also sustained approximately one million jobs. Furthermore, rail, road and port development is spurred on by the development of new and extended mining operations. New towns are established in mineral rich areas and attract investment into the economy.

South Africa holds a major economic and physical presence on the African continent and the world at large regarding mining. About a quarter of South Africa's exports come from mining. South Africa ranks number five in the world in gold production. ${ }^{6}$ It is the largest producer of platinum in the world. ${ }^{7}$ It produces $80 \%$ of the world's platinum. ${ }^{8}$ Anglo-American Platinum is the world's largest platinum and palladium producer. ${ }^{9}$ Other major producers are Impala Platinum, Northam Platinum, Aquarius Platinum and Lonmin Platinum.

\section{Mining Communities and Mine Workers}

While mining has been the mainstay of the economy and has contributed significantly to the industrial development of the country ${ }^{10}$ its impact on the mine workers and the mining communities has not been that positive. For communities around the platinum mines as has been well documented in a number of studies by the Bench Marks Foundation, ${ }^{11}$ life is harsh. The majority of the people in these communities live in tiny houses or shacks, with no access to clean water or decent sanitization. According to the Bench Marks Foundation, the water sources surrounding the townships and informal settlements are often heavily polluted partly from the mining activities. ${ }^{12}$ Furthermore, the few services that are provided by the mining companies through corporate social responsibility programmes are reported to be mostly of an appalling standard. ${ }^{13}$ According to the Bench Marks Foundation report, the corporate social responsibility programmes in the

\footnotetext{
${ }^{3}$ National Accounts - Statistics South Africa, available at http://www.statssa.gov.za/publications/D04052/D040522008.pdf, accessed on 10 January 2013.

${ }_{4}^{4}$ Mining and minerals in South Africa (available at: http://www.southafrica.info/business/economy/sectors/mining.htm), as accessed on 1 February 2012.

5 Ibid.

${ }^{6}$ See, "China, Ghana gold production spike, others fall" available at http://www.mining.com/world-gold-production-2012-preliminaryresults-71758/, accessed on 16 February 2013. South Africa was the world's largest gold producer until 2007 when China became the largest producer of gold. China continued to increase gold production (extraction) and remained the leading gold-producing nation in 2009, followed by Australia.

7 See Platinum Today, available at http://www.platinum.matthey.com/about-pgm/production, accessed on 12 March 2013.

${ }^{8}$ See "What South Africa Means To The Platinum Market" available at http://commodityhq.com/2012/what-south-africa-means-to-theplatinum-market/ accessed on 10 March 2013

9 See Anglo American Platinum, available at http://www.angloplatinum.com/, accessed on 24 November 2012.

10 See National Accounts, Statistics South Africa, available at http://www.statssa.gov.za/publications/D04052/D040522008.pdf accessed on 10 January 2013.

11 See the following studies: The Bench Marks Foundation, "A Review of the Corporate Social Responsibility Programmes of the Platinum Industry in the North West Province," (2007); "Review of the Corporate Social Responsibility Programmes of the Platinum, Coal, Gold and Uranium Mining Sectors in South Africa," (2008); "A Review of Platinum Mining in the Bojanela District of the North West Province" (2012) - all available at http://www.bench-marks.org.za, accessed on 10 September 2012.

12 The Bench Marks Foundation, "Communities in the Platinum Fields" available at http://www.bench-marks.org.za/research/rustenburg _review_policy_gap_final_aug_2012.pdf accessed on 10 September 2012.

13 The Bench Marks Foundation, "Communities in the Platinum Fields" available at http://www.bench-marks.org.za/research/rustenburg _review_policy_gap_final_aug_2012.pdf accessed on 10 September 2012.
} 
platinum belt are "top-down, designed by experts and imposed on communities and there is very little evidence that communities, as stakeholders, are actually consulted about their needs, or about their frustrations concerning the impact of mining operations on their lives." 14

The Bench Marks Foundation criticized the high profits when compared with the low wages of the workers. According to the Bench Marks Foundation the benefits of mining are not reaching the workers or the surrounding communities. ${ }^{15}$ In this regard, it would not be an overstatement that the expansion of the mining companies in South Africa was and still is being driven by inter alia the availability of the supply of cheap labour that ensures that healthy profit margins are attained.

\section{The Role of Government in the Mining Sector}

The role of government in the mining sector is evident in a number of legislation concerning sustainable mining practices. Examples in this regard are the Mineral and Petroleum Resources Development Act, ${ }^{16}$ the National Environment Management Act, ${ }^{17}$ the National Water Act $^{18}$ and the Mine Health and Safety Act. ${ }^{19}$ These statutes together with the Broad Based Socio-Economic Empowerment Charter for The South African Mining and Minerals Industry are discussed seriatim below.

\subsection{The Mineral and Petroleum Resources Development Act}

The Mineral and Petroleum Resources Development Act acknowledges that the country's mineral resources belong to the nation. ${ }^{20}$ The State is subsequently appointed as custodian of these resources. As custodian the State has the ultimate responsibility to grant, issue, control, administer and manage all rights in minerals. ${ }^{21}$ More importantly, in terms of the MPRDA the government has a mandate to ensure the sustainable development of the country's mineral and petroleum resources within a framework of national environmental policy, norms and standards while promoting economic and social development. ${ }^{22}$

The MPRDA regulates the processes and management of Prospecting and Mining activities. In order to conduct mining activities, a mining right or mining permit will be required and for prospecting activities, a prospecting right will be required. Any person conducting prospecting must comply with an approved Environmental Management Plan (EMP). ${ }^{23}$ An EMP is defined as a plan to manage and rehabilitate environmental impacts associated with prospecting. ${ }^{24}$ Any person conducting mining must comply with an approved Environmental Management Programme (EMPR). ${ }^{25}$ The EMPR is prepared following an environmental impact assessment as prescribed in terms of the MPRDA. ${ }^{26}$ Decisions to approve (or refuse) EMPs or EMPRs are taken by the Department of Mineral Resources.

\subsection{The National Environment Management Act}

Mining and certain developments and activities (which are listed under various laws) which may have an impact on the environment require authorization before they may commence. ${ }^{27}$ In South Africa, the Environmental Impact Assessment

\footnotetext{
$14 \mathrm{lbid}$.

15 See The Bench Marks Foundation, "Communities in the Platinum Fields" available at http://www.bench-marks.org.za/research /rustenburg_review_policy_gap_final_aug_2012.pdf, accessed on 10 September 2012.

16 The Mineral and Petroleum Resources Development Act 28 of 2002. Hereinafter, the MPRDA.

17 The National Environment Management Act 107 of 1998. Hereinafter, NEMA.

18 The National Water Act 36 of 1998. Hereinafter, NWA.

19 The Mine Health and Safety Act 29 of 1996.

20 Section 3.

21 Section 3(2).

22 See section 3(3).

23 See section 39 of the MPRDA.

24 See section 1 of the MPRDA.

25 This is defined in section 1 of the MPRDA to mean "an approved environmental management programme contemplated in section 39." Every person who applies for a mining right in terms of section 22 must conduct an environmental impact assessment and submit an environmental management programme for approval.

${ }^{26}$ See section 39 of the MPRDA

27 Section 24(2) of NEMA.
} 
(EIA) Regulations, which were published in terms of the National Environmental Management Act (NEMA), currently regulate General Development. ${ }^{28}$ Depending on the nature of the activity, the NEMA EIA Regulations may require either a basic assessment or a scoping and EIA before an environmental authorization may be granted. Environmental authorizations are granted (or refused) by the Department of Environmental Affairs or the relevant provincial environment department. The commencement of a listed activity without environmental authorization is regarded as an offence. ${ }^{29} \mathrm{~A}$ failure to obtain such authorization may result in imprisonment for a period not exceeding 10 years or a fine not exceeding R5 million (or both).

\subsection{The National Water Act}

Many mining activities will also trigger a requirement for other environmental approvals and processes. For example, a mine may need to store water which, in addition to being an activity requiring environmental authorization, will also require a water use licence in terms of the National Water Act, (NWA). ${ }^{30}$ The NWA requires almost all water uses (abstraction, storage, waste disposal, discharge, removal of underground water and alteration to water courses) above certain thresholds to be licensed and registered. ${ }^{31}$ Water uses for which licensing is required but which are not licensed and registered are illegal and may inter alia result in a fine or a directive to cease the specific operation or activity. ${ }^{32}$

\subsection{The Mine Health and Safety Act}

The Mine Health and Safety Act 29 of 1996 provides for the protection of the health and safety of employees and other persons affected by the South African mining industry and, amongst others, provides for the promotion of a culture of health and safety as well as the enforcement of health and safety measures or legislation. The main functions of the Mine Health and Safety Inspectorate established in terms of section 47 of the Mine Health and Safety Act are inter alia the provision of policy inputs for the establishment and application of mine safety standards at mining operations, policy inputs towards the establishment and application of mine equipment safety standards at mining operations, the establishment and application of mine health standards at mining operations and the promotion of these applications and ensuring an effective support and inspection service. The activities of the Inspectorate are geared to achieve strategic objectives such as to actively contribute to sustainable development and growth, regulate the minerals sector and to promote health and safety in the minerals sector.

\subsection{Broad Based Socio-Economic Empowerment Charter for The South African Mining and Minerals Industry}

The government, like many other governments globally endowed with abundant mineral resources, developed policies to accelerate the pace of the transformation of the mining sector. On 11 October 2002, the Department of Minerals and Energy ${ }^{33}$ together with mining industry stakeholders, including the Chamber of Mines, South African Mining Development Association and the National Union of Mine Workers signed the Broad Based Socio-Economic Empowerment Charter for The South African Mining and Minerals Industry. In September 2010 government launched a new Mining Charter. ${ }^{34}$ The Mining Charter 2010 provides as one of its objectives, to promote employment and advance the social and economic welfare of mine communities and major labour sending areas. ${ }^{35} \mathrm{It}$ also inter alia requires mining companies to ensure that there is a meaningful contribution towards community development, both in terms of size and impact, in keeping with

28 The NEMA EIA Regulations and Listing Notices published in 2010 repeal and replace the listed activities identified in terms of GNR 386 and 387 of 21 April 2006 and set out the new list of activities and competent authorities identified in terms of sections 24(2) and 24D of NEMA. The 2010 NEMA EIA Regulations came into effect on 2 August 2010.

${ }^{29}$ See section $24 F$ of NEMA.

30 Section 22 read with section 21 of the NWA.

${ }^{31} \mathrm{lbid}$.

32 Section 152 of the NWA.

${ }^{33}$ Now the Department of Mineral Resources.

34 Hereafter, the Mining Charter 2010. This new Charter is aimed at addressing various shortcomings in the implementation of the Mining Charter of 2002. The Mining Charter of 2002 was accused of having failed to consider the rights of communities in terms of community consultation; community input into planning for mining developments; direct community control of shares in mining companies-see Tapula T, "Making the Mining Charter Go Further Towards Genuine Empowerment" available at http://www.saiia.org.za lopinion-analysis/making-the-mining-charter-go-further-towards-genuine-empowerment, accessed on 29 December 2012.

${ }^{35}$ See section 1(d) of the Mining Charter. 
the principles of the social licence to operate. ${ }^{36}$ The Mining Charter 2010 further states that mining companies must implement measures to improve the standards of housing and living conditions of mineworkers. ${ }^{37}$

\subsection{The Enforcement of the Mining Industry's Legal Obligations}

While the government's mandate is beyond dispute, there has been lack of political will on the part of government to enforce the industry's legal obligations as evidenced by the discussed plight of the mine workers and communities in which mining activities takes place. While various factors can be attributed to government's failure to strongly enforce the mining industry's legal obligations, the following three factors will be discussed.

Firstly, it is submitted that government's the lack of political will can be attributed to the fear that it would lose credibility with other potential investors and financiers. This fear emanates from the fact that South Africa's economy is open to international trade and as a result subject to external influences such as changes in the behaviour pattern of the foreign investors and trade partners. In light of this fact, government appears to have become hesitant about implementing progressive economic policies that could address for instance, unemployment and poverty for fear that these policies will drive down share prices and create a negative view of South African policies in international financial markets and the business media.

Secondly, the fear that mobile capital and production will flee onerous regulatory jurisdictions can also be attributed to government's unwillingness to strong enforce the mining industry's obligations. ${ }^{38}$ It is thus, not surprising that throughout the Marikana massacre in which striking mine workers at the Lonmim Platinum mine were gunned down by members of the South African Police Services in 2012, key government ministers, including the Minister for Mineral Resources and the Minister of Trade and Industry openly attempted to assure foreign investors that South Africa is a safe destination for investment and that investments in mining are very secure. However, ironically, government's policies have had a hand in facilitating capital flight. For instance, since the introduction of the Growth, Employment and Redistribution ${ }^{39}$ policy ${ }^{40}$ controls on outward flowing capital have been eased year on year in order to facilitate the international expansion of South African companies. In the mid-1990s South African companies were allowed to take up to R750 million out of the country, by 2004 this figure had increased to R 2 billion. ${ }^{41}$ Furthermore, permission was granted to large companies to list offshore. Since the late 1990s, a large number of South African companies have their primary listing offshore. The result of offshore listing was that many large South African companies were no longer South African and that they were investing capital produced in South Africa over 150 years to expand their internationalized companies. It is worth remembering that much of that capital was generated in exploiting the non-renewable mineral wealth of South Africa and in harsh exploitation of the South African mineworkers.

Thirdly, according to The Bench Marks Foundation political patronage is one of the many factors that can be attributed to the government's failure to properly address issues arising in corporate governance. Having politicians or civil servants and, or their family members on the boards of mining companies or as black economic-empowerment (BEE) partners is problematic. The reasons are clearly articulated by the Bench Marks Foundation. ${ }^{42}$ These inter alia include the fact that the regulatory role of government is compromised if senior figures from the ruling political party are also beneficiaries of mining; the legislative and oversight roles of parliament are compromised if senior parliamentarians of the majority and other parties are also beneficiaries of mining; and the fact that the role of the state as neutral arbiter in disputes between ordinary citizens and communities on the one hand and companies on the other is compromised.

\footnotetext{
${ }^{36}$ See provision 2.6

37 See provision 2.7.

${ }^{38}$ Mooletsi Mbeki once remarked "big companies taking their capital out of South Africa are a bigger threat to economic freedom than [then] ANC Youth League President Jullius Malema" - See Business Report - "Mbeki: Capital Flight is a Threat," available at http://www.iol.co.za/business/business-news/mbeki-capital-flight-is-a-threat-1.1131398, accessed on 18 November 2011.

${ }^{39}$ Hereafter, GEAR.

40 Through GEAR, the South African state has privatized or commercialized various public entities, implemented trade liberalization and allowed for some labour market flexibility.

${ }^{41}$ Hattingh S, "BHP Billiton and SAB: Outward Capital Movement and the International Expansion of South African Corporate Giants," accessed on 06 March 2011, available at http://www.taxjustice.net/cms/upload/pdf/llrig_0809_South_African_giants.pdf.

42 The Bench Marks Foundation, "Communities in the Platinum Fields" available at http://www.bench-marks.org.za/research/rustenburg _review_policy_gap_final_aug_2012.pdf, accessed on 10 September 2012.
} 


\section{Recommendations}

In light of the identified challenges, the following recommendations are made. Firstly, it is recommended that government should ensure the protection of stakeholder interests in the mining industry. For instance, government should investigate the appalling conditions under which communities near mining operations live, in particular in the informal communities that spring up around mines. This should also be seen in light of the Millennium Development Goals 'target 7' that includes reducing the number of slum areas. ${ }^{43}$

Secondly, it is recommended that legislation concerning sustainable mining practices should always be enforced strongly. South Africa possesses sufficient legislation concerning sustainable mining practices. As has been highlighted, examples in this regard are the Mineral and Petroleum Resources Development Act, the National Environment Management Act, the National Water Act and the Mine Health and Safety Act. Penalties for not complying with sustainability requirements in terms of these Acts can be significant in terms of monetary fines levied for violations. In extreme cases, mining licences can be suspended or even revoked if mining companies are found to be in contravention of any or all of the Acts. However, the legislation is not always enforced as strongly as it should be. It is in this regard that it is recommended that legislation concerning sustainable mining practices should always be enforced strongly.

Thirdly, it is recommended that senior politicians and civil servants should be barred from serving on the boards of mining companies.

Fourthly, it is recommended that government should ensure sustainable development in the mining industry. In order for the mining industry to promote sustainable development among the mining communities, the government must have robust and clear policies for revenue sharing for mining communities. Government should devise ways of distributing equitably, on an agreed upon formula/percentage, the taxation revenues/royalties collected from mining companies to meet the needs of affected mining communities. These funds must meet the short, medium and long-term needs and aspirations of mining communities. This is to address the deepening poverty and marginalization of many local communities, despite mining taking place in their areas. Further, equitable funds should be put aside to ensure continuance of community life when mining ends.

\section{Conclusion}

Government has an important role to play in the mining sector in ensuring the protection of stakeholders' interests and promoting sustainable development by mining companies. In light with this role, it has been argued that there appears to be lack of political will on the part of government to enforce the industry's legal obligations with regard to corporate social responsibility. Recommendations aimed at addressing this challenge have been made. While it has been inter alia recommended that government should strongly enforce the industry's obligations, it is submitted that it is crucial that there is co-operation between government and the mining industry. A fractious relationship between government and the mining industry is disastrous. Proper engagement needs to happen.

\section{References}

Alexander P, Lekgowa T, Mmope B, Sinwell L and Xeswi B, Marikana: A View from the Mountain and a Case to Answer (2012) Jacana Media.

Alexander P, Lekgowa T, Mmope B, Sinwell L and Xeswi B, Marikana: Voices from South Africa's Mining Massacre (2013) Ohio University Press.

Davies D, Cassim F, Geach W, Mongalo T, Butler D, Loubser A, Coetzee L and Burdett D, Companies and Other Business Structures in South Africa $2^{\text {nd }}$ Edition (2011) Oxford University Press Southern Africa.

Hendrikse JW and Hefer-Hendrikse L Corporate Governance Handbook 2nd Edition 2004 Juta\& Co. Ltd.

Seccombe A, "Amplants bows to State Pressure in Retrenchment Talks" available at http://www.bdlive.co.za/business/mining/2013/01 /29/amplats-bows-to-state-pressure-in-retrench ment-talks, accessed on 12 February 2013.

Statistics South Africa, available at http://www.stassa.gov.za/keyindicators/GDP/GPP_1stQuarter2013_Press_Statement.pdf accessed on 10 June 2013.

Tapula T, "Making the Mining Charter Go Further Towards Genuine Empowerment" available at http://www.saiia.org.za/opinionanalysis/making-the-mining-charter-go-further-towards-genuine-empowerment, accessed on 29 December 2012.

${ }^{43}$ See the Millennium Development Goals Report 2013, Target 7.D By 2020, to have achieved a significant improvement in the lives of at least 100 million slum dwellers. Available at http://www.un.org/millenniumgoals/pdf/report-2013/mdg-report-2013-english.pdf, accessed on 10 March 2013. 
The Bench Marks Foundation, "Communities in the Platinum Fields" available at http://www.bench-marks.org.za/research/rustenburg _review_policy_gap_final_aug_2012.pdf, accessed on 10 September 2012.

Colemān N, "More Questions Thän Answers," Mail and Guardian, 26 October - 1 November 2012.

Corporate Watch, "Blood Money, Shock Revelations and Media Half-Truths on South African Mine Violations" (2013) available at http://www.corporatewatch.org/?lid=4741, accessed on 25 March 2013.

ILO news, available at http://www.ilo.org/global/about-the-lo/newsroom/news/WCMS_187783/lang --en/index.htm, accessed on 22 January 2013.

De Vos P, "Some Thoughts on the Marikana Massacre," available at http://constitutionallyspeaking.co.za/some-thoughts-on-themarikana-massacre. accessed on 25 September 2012. 
